\title{
Correction to: Validation of the Community Integration Scale for Adults with Psychiatric Disorders (CIS-APP-34)
}

\author{
Joana Cabral ${ }^{1,3,4} \cdot$ Célia Barreto Carvalho $^{1,2} \cdot$ Carolina da Motta $^{1,2} \cdot$ Marina Sousa $^{1}$
}

Published online: 23 February 2018

(c) Springer Science+Business Media, LLC, part of Springer Nature 2018

\section{Correction to: Community Mental Health Journal}

\section{https://doi.org/10.1007/s10597-017-0228-2}

The original version of the article unfortunately contained a typo in the author name. The co-author name should be "Carolina da Motta" instead of "Carrolina da Motta".

The original article has been corrected.

Joana Cabral

joana.m.cabral@uac.pt

Célia Barreto Carvalho

celia.mo.carvalho@uac.pt

Carolina da Motta

carolina.d.motta@uac.pt

Marina Sousa

marina.c.sousa@uac.pt

1 University of Azores, Ponta Delgada, Portugal

2 Cognitive and Behavioural Center for Research and Intervention, University of Coimbra, Coimbra, Portugal

3 Faculty of Social and Human Sciences, University of the Azores, Rua Mãe Deus, 9500-321 Ponta Delgada, Portugal

4 Apartado 1422, 9501-801 Ponta Delgada, Açores, Portugal 